\title{
Mechanical Properties of Fly Ash Polymer Concrete with Different Fibers
}

\author{
MARINELA BARBUTA ${ }^{1 *}$, ALEXANDRU TIMU1 ${ }^{1}$, LILIANA BEJ AN ${ }^{1}$, ROXANA DANA BUCUR ${ }^{2}$ \\ ${ }^{1}$ Technical University Gh. Asachi from lasi, 43 Mangeron Blvd., 700050, lasi, Romania \\ ${ }^{2}$ University of Agricultural Sciences and Veterinary Medicine in lasi, 3 Sadoveanu Alley, 700490, Iasi, Romania
}

\begin{abstract}
The experimental results obtained by studying the influence of different types of fibers on the mechanical properties of fly ash polymer concrete are presented in the paper. The general demand of using wastes found applicability in building material industry because some of them are beneficial in improving concrete properties. The waste additions type fly ash and fibers were incorporated in polymer concrete. The study focused on fibers type glass, polyester, metallic and cellulose. The mechanical properties such as compressive strength, flexural strength and split tensile strength were investigated having in view the type, dosage and length of fibers. The results show that fibers improved mechanical properties in comparison with that of polymer concrete without fibers, the test results being differently influenced by the factors which were considered.
\end{abstract}

Keywords: Fiber reinforcement, flexural strength, polymer concrete, compressive strength, tensile strength, fly ash

Building materials industry has developed a lot of new materials which mustrespond to the modern requirements from construction field and to the necessities related to the environment protection [1-3]. A great number of construction materials are obtained with/from wastes, which are an important problem in environment pollution and storage costs [4]. The concrete is one of the most used products in construction industry and it is often associated to wastes of different types: powder, fibers, granules, nano-particles, etc.[5-8]. As addition or replacement of cement in concrete and cement component are used many wastes, such as: silica fume [9-11], fly ash [12], ground granulated blast furnace [13, 14], sludge [15, 16], waste ferrochromium [17], tire wastes $[18,19]$, bagasse ash [20], rice husk ash [21], bamboo leaf ash [22, 23], ceramic waste [24], etc.

The effects of fibers on cement concrete and composite materials have been studied and reported in articles by numerous researchers [1-3, 22-29]. In reinforcing polymer concrete a lot of types of fibers can be used: glass, carbon, boron, steel, polyester, polypropylene, etc. or natural fibers like: hemp, coconut, banana fibers, sugar cane bagasse, cellulose. The mechanical properties depend on the type and dosage of fiber [3, 30, 31]. Most of studies reported that glass fibers, carbon and metallic fibers improved the post-peak behavior of polymer concrete [3, 32, 33]. The strength and toughness also increased with addition of fibers [34]. In the paper [35] authors reported that textile fibers do not increase polymer concrete flexural and compressive strength but their addition to the mixture eliminates the signs of brittleness behavior of unreinforced polymer concrete. In paper [36] is reported a study which evaluates the use of recycled fibers from carpet industrial waste. Significant increases in shatter resistance, energy absorption and ductility were observed. The uses of natural fibers, as reinforcement are economical for increasing their tensile strength, shear strength, toughness and/or combinations of these [37]. An investigation of the mechanical characterization (flexural strength, fracture toughness and fracture energy) of epoxy polymer concrete reinforced with natural fibers (coconut, sugar cane bagasse, and banana fibers) had shown that these properties can be increased and also the flexural strength can be slightly increased by using coconut fiber only [38]. In this study the mechanical characteristics such as compressive strength, flexural strength and split tensile strength were investigated on polymer concrete made with fly ash and different types of fibers wastes.

\section{Experimental part}

Research Significance

A significant amount of wastes of different types is disposed worldwide. They are not only an environmental concern, but also by using them the resources can be protected. This paper completes the knowledge referred to the characteristics of polymer concrete made with wastes. This type of polymer was not sufficiently studied in the last years because the high costs of polymer [39, 40]. Using wastes for obtaining the polymer concrete is a possibility of obtaining this material at lower prices. The research study presents the mechanical properties of new products obtained with fly ash and different fibers wastes in order to determine their usefulness. New studies are required in this field for promotion and use of these materials in construction industry.

\section{Materials}

For studying the influence of fibers on mechanical properties of fly ash polymer concrete the following components were used: epoxy resin, fly ash as filler and two sorts of aggregate $(0-4 \mathrm{~mm}$ and $4-8 \mathrm{~mm})$. To the witness mix different types of fibers were added: glass fibers, (GF), polyester fibers, (PesF), metallic fibers (MF) and cellulose fibers (CF) (table 1).

The polymer was type epoxy resin, called ROPOXID, made in Romania by POLICOLOR Bucharest [41]. The hardener was type ROMANID 407, also made by POLICOLOR Bucharest [41].

The fly ash (FA), a waste from the power plant CET Holboca lasi was added to the aggregates [42]. Fly ash was type $F$ ash, with a gray color, small particles ranging in size from 0.01 to $100 \mathrm{im}$ and its chemical composition 


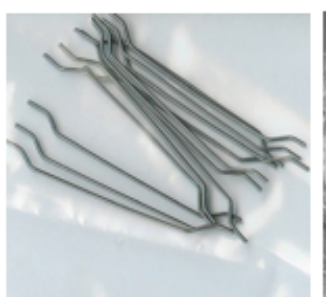

a-mettalic fiber

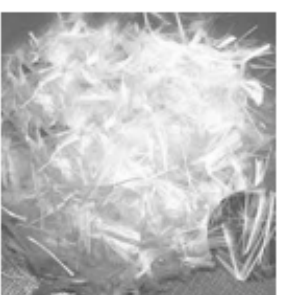

b-glass fiber

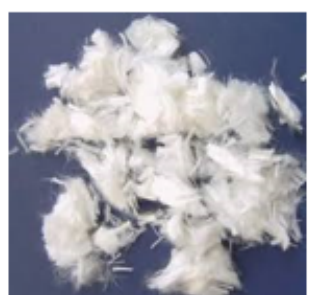

c-polyester fiber

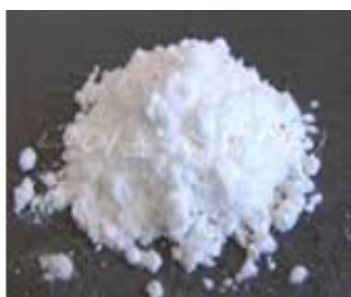

d-ARBOCEL fiber
Fig. 1. Type of fibers

\begin{tabular}{|c|c|c|c|c|c|c|c|c|c|c|c|}
\hline \multirow{3}{*}{ Sample } & \multirow{3}{*}{$\begin{array}{c}\text { Epoxy } \\
\text { resin } \\
\%\end{array}$} & \multirow{3}{*}{$\begin{array}{c}\text { Fly ash } \\
\%\end{array}$} & \multicolumn{2}{|c|}{ Aggregate \% } & \multicolumn{7}{|c|}{ Fibers } \\
\hline & & & \multirow[t]{2}{*}{ Sort I } & \multirow[t]{2}{*}{ Sort II } & \multicolumn{2}{|l|}{ GF } & \multicolumn{2}{|c|}{ PesF } & \multicolumn{2}{|c|}{ MF } & \multirow{2}{*}{$\begin{array}{l}\text { CF } \\
\%\end{array}$} \\
\hline & & & & & $\mathrm{L}(\mathrm{mm})$ & $\%$ & $\begin{array}{c}\mathrm{L} \\
(\mathrm{mm})\end{array}$ & $\%$ & $\begin{array}{c}\mathrm{L} \\
(\mathrm{mm})\end{array}$ & $\%$ & \\
\hline PC - witness & 12.4 & - & 43.8 & 43.8 & - & - & - & - & - & - & - \\
\hline PCGF1 & 12.4 & 12.8 & 37.4 & 37.4 & 50 & 0.5 & - & - & - & - & - \\
\hline PCGF2 & 12.4 & 12.8 & 37.4 & 37.4 & 30 & 0.5 & - & - & - & - & - \\
\hline PCGF3 & 12.4 & 12.8 & 37.4 & 37.4 & 10 & 0.5 & - & - & - & - & - \\
\hline PCPesF1 & 12.4 & 12.8 & 37.4 & 37.4 & - & - & 50 & 0.5 & - & - & - \\
\hline PCPesF2 & 12.4 & 12.8 & 37.4 & 37.4 & - & - & 30 & 0.5 & - & - & - \\
\hline PCPesF3 & 12.4 & 12.8 & 37.4 & 37.4 & - & - & 10 & 0.5 & - & - & - \\
\hline PCMF1 & 12.4 & 12.8 & 37.4 & 37.4 & - & - & - & - & 50 & 2 & - \\
\hline PCMF2 & 12.4 & 12.8 & 37.4 & 37.4 & - & - & - & - & 25 & 2 & - \\
\hline PCMF3 & 12.4 & 12.8 & 37.4 & 37.4 & - & - & - & - & 50 & 7 & - \\
\hline PCFM4 & 12.4 & 12.8 & 37.4 & 37.4 & - & - & - & - & 25 & 7 & - \\
\hline PCCF1 & 12.4 & 12.8 & 37.4 & 37.4 & - & - & - & - & - & - & 0.25 \\
\hline PCCF2 & 12.4 & 6.4 & 40.6 & 40.6 & - & - & - & - & - & - & 0.25 \\
\hline
\end{tabular}

Table 1

COMPOSITION OF POLYMER

CONCRETE WITH

WASTES with oxides, hydroxides, carbonates, silicates, and sulfates of calcium, iron and aluminum [41].

The aggregates were used in two sorts: 0-4 mm (sand) and 4-8 mm, with continuous granulosity, obtained from crushed river gravel.

The glass fibers (fig. 1 b) were wastes from industry which were cut at different lengths: $10 \mathrm{~mm}, 30 \mathrm{~mm}$ and $50 \mathrm{~mm}$. the characteristics of glass fibers type Glass fiber 2040 dtex are: yarn tensile strength $72.64 \mathrm{~N}$ and tenacity $66.98 \mathrm{cN} /$ tex [42]. The glass fibers were used in a dosage of $0.5 \%$ from the mix weight.

The polyester fibers (fig. $1 \mathrm{c}$ ) are also wastes which were cut at $50 \mathrm{~mm}, 30 \mathrm{~mm}$ and $10 \mathrm{~mm}$. The characteristics of Polyester fibers type PES HT 110 dtex are: yarn tensile strength $42.21 \mathrm{~N}$ and tenacity $20.69 \mathrm{cN} /$ tex [43].

The glass and polyester fibers were used in a dosage of $0.5 \%$ from the mix weight.

The metallic fibers (fig. 1 a) had different lengths, of 50 $\mathrm{mm}$ and $25 \mathrm{~mm}$ (these were half of long fibers).

The ARBOCEL fibers (fig. $1 \mathrm{~d}$ ) were natural cellulose fibers, produced by J. Rettenmaier \& Sohne GMBH. The ARBOCEL cellulose fibers had the mean fiber length of 10 $\mu \mathrm{m}$. The fiber dosage was of $0.25 \%$ from the mix weight.

\section{Experimental samples}

The mixes presented in the article were chosen from previous experimental results effectuated on each type of fiber with more types of components dosages, table 1. The criterion for chosen samples was the value of compressive strength obtained experimentally which was considered with maximum value. In the case of glass fibers and polyester fiber are analyzed the mixes with different lengths and maximum dosage of fiber. In the case of metallic fibers are analyzed the mixes with different lengths and dosages (because a dosage of $7 \%$ from the weight is not maximum). In the case of cellulose fiber was analyzed the mixes with maximum and minim dosage of fly ash dosage which allow the same dosage of $12.4 \%$ of epoxy resin, with the fiber with maximum dosage and the same length.

The glass fibers and polystyrene fibers were of three sizes: $50 \mathrm{~mm}, 30 \mathrm{~mm}$ and $10 \mathrm{~mm}$. For glass fiber polymer concrete, the notations were: PCGF 1 for $50 \mathrm{~mm}$ length, PCGF2 for $30 \mathrm{~mm}$ and PCGF3 for $10 \mathrm{~mm}$ length and for polyester fiber polymer concrete the notations were: (PCPesF1) for $50 \mathrm{~mm}, \mathrm{PCPesF} 2$ for $30 \mathrm{~mm}$ and PCPesF3 for $10 \mathrm{~mm}$ length. The proportion used in polymer composition was of $0.5 \%$ from the mix weight (this was the maximum dosage of fiber imposed from the workability condition).

For polymer concrete with metallic fiber (FM) the notations were: PCMF1 for $50 \mathrm{~mm}$ length and a dosage of $2 \%$ from the mix weight, PCMF2 for $25 \mathrm{~mm}$ length (half from the long fiber) and a dosage of $2 \%$ from the mix weight, PCMF3 for $50 \mathrm{~mm}$ length and a dosage of $7 \%$ from the mix weight and PCM4 for $25 \mathrm{~mm}$ length and a dosage of $7 \%$.

For polymer concrete with cellulose fibers the dosage of fiber was the same $(0.25 \%$ from the mix weight) and the fly ash dosage was $12.8 \%$ for PCCF1 and $6.4 \%$ for PCCF2.

For studying the influence of fibers on mechanical properties of fly ash polymer concrete the same mix was used (12.4\% epoxy resin, $12.8 \%$ fly ash and the tw 0 sorts of aggregates in equal dosage of $37.4 \%$ ) for the witness and for the composition with fibers. 
The fly ash was mixed with aggregates and then the resin (combined with hardener) was added in the mechanical mixer. During mixing, the fibers were introduced. After complete mixing, the polymer concrete was poured in formworks. The following mechanical characteristics were experimentally tested at 14 days: compressive strength $(f)$ on cube samples of $70 \mathrm{~mm}$ sizes, flexural strength $\left(f_{t}\right)$ and split tensile strength $\left(f_{t d}\right)$ on prismatic samples of sizes $210 \times 70 \times 70 \mathrm{~mm}$, according to European standard prescriptions [43-45].

\section{Results and discussions}

The results of mechanical properties obtained by laboratory tests according to [43-45] as average of three tests are given in table 2 .

The experimental results are compared in the graph presented in figure 2 .

\section{Compressive strength}

All types of fibers, except cellulose fibers, improved the compressive strength of polymer concrete with fly ash in comparison with that of witness, (table 2, fig. 2). The highest value $f=106.85 \mathrm{MPa}$, was obtained for polymer concrete which contains glass fiber with $50 \mathrm{~mm}$ length and a maximum dosage, in which case the increase in strength was of about $52.8 \%$. All lengths of glass fibers increased the compressive strength with percentages between 33 and $52.8 \%$ and the higher lengths results in higher values of the property.

\section{Table 2}

MECHANICAL CHARACTERISTICS OF POLYMER CONCRETE WITH FIBERS

\begin{tabular}{|c|c|c|c|c|}
\hline & Sample & $\mathrm{fc}, \mathrm{MPa}$ & $\mathrm{fti}, \mathrm{MPa}$ & ftd, $\mathrm{MPa}$ \\
\hline 1 & Witness & 69.93 & 12.26 & 6.82 \\
\hline 2 & $\mathrm{PCGF}^{-}$ & 106.85 & 16.73 & 10.11 \\
\hline 3 & PCGF2- & $98.73^{-}$ & $16.93^{-}$ & $7.78^{-}$ \\
\hline 4 & $\mathrm{PCGF}^{-}$ & 93.03 & $17.25^{-}$ & 8.40 \\
\hline 5 & PCPesF1 & 88.03 & 15.62 & 11.82 \\
\hline 6 & PCPesF2 & 80.6 & 16.36 & 7.02 \\
\hline 7 & PCPesF3 & 95.54 & $16.05^{-}$ & 12.2 \\
\hline 8 & PCMF1 & $88.90^{-}$ & 17.1 & 6.54 \\
\hline 9 & PCMF2 & 89.18 & $15.3^{-}$ & $9.10^{-}$ \\
\hline 10 & PCMF3 & 102.41 & 23.4 & 6.36 \\
\hline 11 & PCMF4 & 85.6 & 18.78 & 9.05 \\
\hline 12 & PCCF1 & 55.02 & $14.69^{-}$ & $6.92^{-}$ \\
\hline $13^{-}$ & PCCF2- & 46.41 & 14.18 & $6.91^{--}$ \\
\hline
\end{tabular}

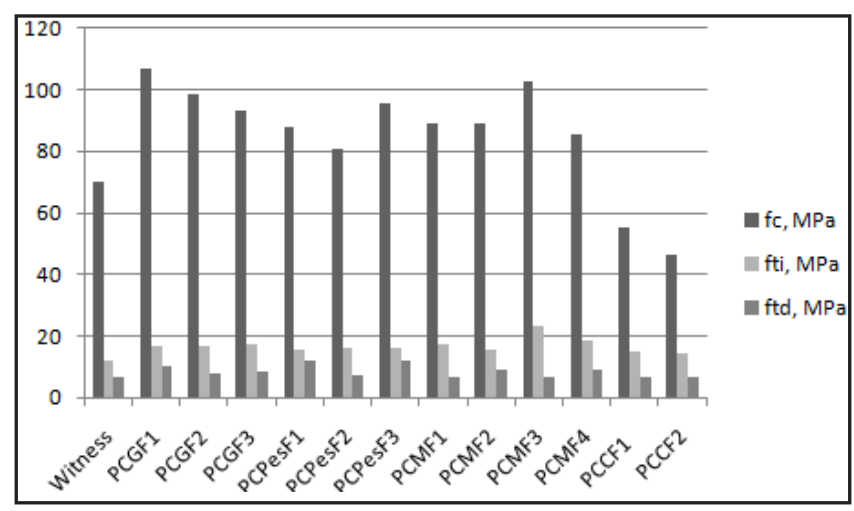

Fig. 2. Variation of mechanical properties of fly ash polymer concrete with different fibers
In the case of polyester fiber the increase in strength was between 15.3 and $36.6 \%$ in comparison with that of the witness and with diminishing the length of the fiber the higher values are obtained. The highest value $f=95.54 \mathrm{MPa}$ was for a length of $10 \mathrm{~mm}$ and maximum dosage of fiber.

In the case of metallic fibers it appeared that the dosage influenced more significantly. The maximum value $f_{c}=102.41 \mathrm{MPa}$ was obtained for a dosage of $7 \%$, which is a huge percent, but it is not the maximum. The increases of strength were between 22.4 and $46.4 \%$ in comparison with that of the witness. For the same length of $50 \mathrm{~mm}$, higher $f$ was obtained for higher dosage (7\%). In the case of length of $25 \mathrm{~mm}$, higherf was obtained for lower dosage of $2 \%$. For the same dosage of fiber of $2 \%$, the length had not significantly influenced the compressive strength. In the case of higher dosage of fiber (7\%), higher $f$ was obtained for higher length. The results were influenced by the ratio between the sizes of the sample and the length of the fiber, having in view that $50 \mathrm{~mm}$ is a long fiber in comparison with the size of the sample which was 70 $\mathrm{mm}$. One explanation is the agglomeration of long fibers which can increase the resistant capacity of the polymer concrete.

The compressive strength obtained in the case of polymer concrete with cellulose fibers was smaller than that of the witness, with percentages between $21 \%$ and $36.6 \%$, the highest value $f_{c}=55.02 \mathrm{MPa}$ was obtained for $a$ bigger content of fly ash.

\section{Flexural strength}

All types of fibers improved the flexural strength of polymer concrete with fly ash. The highest value was obtained for polymer concrete with metallic fiber, (table 2, fig. 2).

The highest value $f_{t}=23.4 \mathrm{MPa}$, was obtained for polymer concrete which contains metallic fiber with 50 $\mathrm{mm}$ length in a dosage of $7 \%$, in which case the increase in strength was of about $90.8 \%$.Comparing the same percentage of fibers and different lengths, it can observe that for a bigger length the flexural strength is higher. Higher dosages of fiber with the same length resulted in higher values of $f_{\text {ti: }}$ All polymer concretes with metallic fibers presented higher values of $f_{t i}$ in comparison with the witness, with percentages between 24.8 and $90.8 \%$ in comparison with the witness.

In the case of glass fibers it appeared that the length did not significantly influence the strength, a small increase is obtained in the case of short fibers. The maximum value $f_{f}=17.25 \mathrm{MPa}$ was obtained for a length of fiber of $10 \mathrm{~mm}$. The increases of strength were between 36.6 and $40.7 \%$ in comparison with that of the witness.

In the case of polyester fiber the increase in strength was between 27.4 and $33.4 \%$ in comparison with that of the witness. The highest value $\mathrm{f}_{\mathrm{ti}}=16.36 \mathrm{MPa}$ was for $a$ length of $30 \mathrm{~mm}$ (a medium value).

The flexural strengths obtained in the case of polymer concrete with cellulose fibers were all higher than that of the witness, but smaller than that of polymer concrete with other types of fibers. The increasing percentages were between 15 and $20 \%$, the highest value $\mathrm{f}_{\mathrm{ti}}=14.69 \mathrm{MPa}$ was obtained for a bigger content of fly ash.

\section{Split tensile strength}

In the case of split tensile strength only PesF, GF and CF increased the strength in comparison with that of witness. The highest value was obtained for polymer concrete with polyester fibers (table 2, fig. 2).

The highest value $f_{\text {td }}=12.2 \mathrm{MPa}$, was obtained for polymer concrete which contains polyester fiber with 10 
$\mathrm{mm}$ length. All lengths of polyester fibers increased the split tensile strength with percentages between 3 and $78.9 \%$. In this case it appears that distribution of fibers in concrete matrix is of significantly importance, the length is less important.

In the case of glass fibers the maximum value $f_{t d}=10.11$ $\mathrm{MPa}$ was obtained for a length of fiber of $50 \mathrm{~mm}$. The increases of strength were between 14 and $48.2 \%$ in comparison with that of the witness.

In the case of metallic fiber the highest value $f_{t+d}=9.1$ MPa was for a length of $25 \mathrm{~mm}$ and a dosage of fiber of $2 \%$. Near to this value was polymer concrete with the same length of fiber and a higher dosage of $7 \%$. The lengths of 50 $\mathrm{mm}$ for both dosages (2 and $7 \%$ ) resulted in the decrease of $f_{\text {in }}$ comparison with the witness.

The split tensile strengths obtained in the case of polymer concrete with cellulose fibers were all a small higher than that of the witness. The highest value $\mathrm{f}_{\mathrm{td}}=6.92$ MPa was obtained for a bigger content of fly ash.

\section{Conclusions}

The mechanical properties were differently influenced by the types of fibers used in experimental tests.

In the case of compressive strength glass, polyester and metallic fibers, improved the compressive strength of polymer concrete with fly ash. The highest value was obtained for polymer concrete with glass fiber. Glass fibers mustbe used in maximum dosage and length for obtaining higher $f_{c}$. Polyester fibers must be used with minimum length and higher dosage in the case of $f_{c}$. Metallic fibers must be used in high dosages for increasing the compressive strength.

All types of fibers improved the flexural strength of polymer concrete with fly ash. The highest value was obtained for polymer concrete with metallic fiber in high dosage. Glass fiber must be used with small length to increase the flexural strength.

In the case of splittensile strength, glass fibers, polyester fiber and cellulose fiber increased the strength. The highest value was obtained for polymer concrete with polyester fibers which had minimum length. Glass fibers must be used with high length in the case of split tensile strength. Metallic fibers presented high values of $f_{t d}$ for minimum length.

In the case of glass fibers, polyester fibers and cellulose fibers the dosage of fibers was maximum from the condition of workability. In the case of metallic fibers the maximum dosage of fibers was not tested because the higher dosage that was used (7\% from the mix weight) was sufficiently big.

The split tensile strength is clearly influenced by the distribution of fibers in the concrete structure and consequently the fiber length influences the type of failure.

For some type of fibers, as in the case of cellulose fibers, the mechanical properties can be increased by using a higher resin dosage, but an increase in epoxy resin dosage results in higher costs. The epoxy resin dosage used in all experiments was minimum established from the workability condition.

In the article were analyzed only the influences of type, length and dosage of fibers on the mechanical properties of epoxy resin concrete with fly ash addition.

The mechanical properties are also influenced by the dosage of fiber, the shape of fibers, type of fibers, fiber distribution, preparing technology, pouring, etc. which are necessary to study for a complete characterization of fiber reinforced polymer concrete and determination of its usefulness as building material.
Acknowledgements: This work was supported by a grant of the Romanian National Authority for Scientific Research and Innovation, CCCDI - UEFISCDI, project number 109 BM / 2017.

\section{References}

1.STELESCU, M., COMEAGA, D., SONMEZ, M., GURAU, D., The Mechanical Properties of Some Polymer Composites Based on Natural Rubber, Mat. Plast., 55, no. 1, 2018, p. 116-120

2.GHIOCA, P., IANCU, L., GRIGORESCU, R. M., SPURCACIU, B., ANDI NICOLAE, C. A., GABOR, A.R., Styrene-diene Block-copolymers Reinforced with Bentonite, Mat. Plast., 54, no. 3, 2017, p. 481-484, 2017

3.BEJ , A., BORDEASU, I., MILOS, T., BADARAU, R., Considerations Concerning the Mechanical Strength of Wind Turbine Blades made of Fiberglass Reinforced Polyester, Mat. Plast., 49, no.3, 2012, p.212-218 4.BOLDEN, J., ABU-LEBDEH, T., FINI E., Am. J. Environ. Sci, 9, no. 1, 2013, p. 14

5.BAYASI, Z., MC INTYRE, M., ACI Mater J, 99, no. 4, 2002, p. 337

6.IGARASHI, S., BENTUR, A., MINDESS, S., Cem. Concr. Compos, 18, 1996, p. 313

7.BORSOS, Z., PAUN, V.P., BOTEZ, I.C,. STOICA, C.M., VIZUREANU, P., AGOP, M., Rev. Chim. (Bucharest), 59, no. 10, 2008, p. 1169 8.PUSCA, S., PAUN, M. A., TOMA, C., Mat. Plast., 44, no. 1, 2007, p.39 9.BARBUTA, M., RUJANU, M., NICUTA, A., Procedia Technology 22, 2016, p.407

10.SINGH, L., BHATTACHARYYE, S., AHALAWAT, S., J. Adv. Concr. Technol. 10, 2012, p. 345

11.HEBA, M., Ain Shams Eng. J., 2, no. 2, 2011, p. 79, doi: 10.1016/ j.asej.2011.06.001.

12.MARIN, E., BARBUTA, M,. CIOBANU, L., CIOARA, I., DUMITRAS, C., J. Optoelectron Adv M, 16, no. 11, 2014, p. 1411

13.BILIM, C., ATIS, C.D., TNYLDIZI, H., KARAHAN, O., Adv. Eng. Software, 40, 2009. p. 334, doi: 10.1016/j.advengsoft.2008.05.005.

14.NAZARI, A., RIAHI, S., Mater. Res, 14, no. 3, 2011, p. 299, doi: 10.1590/S1516-14392011005000052.

15.MONZO, J., PAYA, J., BORRACHERO, M.V., GIRBES, I., Waste Manag, 23, 2003, p. 373, doi:101016/S0956/(03)00034-5.

16.BANFOL, P., FRIAS, M., Cem. Concr. Res, 37, 2007 pp. 184. doi:10.1016/ j.cemconres.2006.11.013.

17.GENCEL, O., KOKSAL, F., OZEL, C., BROSTOW, W., Constr. Build. Mater, 29, 2012, p. 633, doi: 10.1016/j.conbuildmat.2011.11.026.

18.BARBUTA, M. HARJA, M., CIOBANU, G., J. Food Agr. Env, 12 no. 2, 2014, p. 1186

19. BRAVO, M., DE BRITO, J., J . Cleaner Pro, 25, 2012, p. 42, doi:10.1016/ j.jclepro.2011.11.066.

20.AKRAM, T., MEMON, S., OBAID, H., Constr. Build. Mater, 23, 2009, p. 703, doi:10.1016/j.conbuildmat.2008.02.012.

21.CHIDAPRASIRT, P., RUKZON, Z., Constr. Build. Mater, 22 no. 8 , 2008, p. 1601, doi: 10.1016/j.conbuildmat.2007.06.010.

22.DWIVEDI, V.N., SINGH, N.P., DAS, S.S., SINGH, N.B, Int. J. Physical Sci, 1, 2006, p. 106, http://www.academicjournals.org/llPS.

23.VILLAR-COCINA, E., VALENSIA, E., SANTO, S.F., SAVASTANO, H., FRIAS, M., Cem. Concr. Comp, 33, 2011, p. 68, doi:10.1016/ j.cemconcomp.2010.09.003.

24.SANCHEZ DE ROJ AS, M.I., RIVERA, J., FRIAS, M., J. Am. Ceramic Soc, 89, 2006, p. 3701, doi: 10.1111/j.1551-2916.2006.01279.x.

25.UYSAL, M., TANYILDIZI, H., Constr. Build. Mater, 27, no. 2, 2012, p. 404, doi:10.1016/j.conbuildmat.2011.07.028.

26.PARVESH, A., SARBJ IT, S., ALAKESH, M., 52, no 9, 2018, p.1253

27.PELISSER, F., NETO, A.B.D.S.S., LA ROVERE, H.L., DE ANDRADE PINTO, R.C., Constr. Build. Mater. 24, no. 11, 2010, p. 2171,doi:10.1016/ j.conbuildmat.2010.04.041.

28.AWWADA, E., MABSOUT, M., HAMAD, B., FARRAN, M.T., KHATIB, H., Constr. Build. Mater, 35 no. 10, 2012, p.710,. doi:10.1016/ j.conbuildmat.2012.04.119.

29.AWWADA, E., MABSOUT, M., HAMAD, B., M.T., KHATIB, H., Leban Sci. J, 12, no. 1, 2011, p. 109 
30.MARTINEZ BARRERA, G., VIGUERAS SANTIAGO, E., GENCEL, O., HAGG HOBLAND, H.E., J Mater Educ, 33, no. 1-2, 2011, p. 37

31.BORDEASU, I.,MICU, L. M., MITELEA, I.,UTU, I., D., PIRVULESCU, L, D.,SIRBU, N, A., Cavitation Erosion of HVOF Metal-ceramic Composite Coatings Deposited onto Duplex Stainless Steel Substrate, Mat. Plast., 53, 2016, no. 4, p. 781-786

32.REIS, J.M.L., FERREIRA, A.J .M., Constr Build Mater, 18, 2004, p. 523 33.REIS, J.M.L., FERREIRA, A.J.M., Polymer Testing, 22, no. 2, 2003, p. 149

34. BEDI, R., CHANDRA, R., SINGH, S. P., Journal of Composites, vol. 2013, Article ID 948745, 12 pages, 2013. doi:10.1155/2013/948745

35.Reis, J.M.L. Mater Res, 12, no. 1, 2009, p. 63

36.WANG, Y., ZUREICK, AH., CHO, B., SCOTT, DE., J. Mater.Sci., 29, no. 16, 1994, p. 4191, doi:10.1007/BF00414198.

37.MAJ ID, A., J . Civ. Eng. Constr. Technol, 3, no. 3, 2012, p. 80, http:// www.academicjournals.org// CECT, DOI: 10.5897/J CECT11.100.

38.REIS, J.M.L., Constr. Build. Mater., 20, no. 9, 2006, p. 673
39.PAUN, V. P., Mat. Plast., 40, no. 1, 2003, p. 25

40.PAUN, V. P., Mat. Plast., 40, no. 2, 2003, p. 81

41.HARJ A, M., BARBUTA, M., RUSU, L., J. Appl. Sci, 9, no. 1, 2009, p. 88, doi: 10.3923/jas.2009.88.96.

42.MARIN, E., BARBUTA, M., CIOBANU, L., CIOARA, I., 14th Int. Mult. Sci. GeoConf. SGEM, www.sgem.org, SGEM2014 Conf. Proc. Book 4, no. 2, 2014, p. 191, doi:10.5593/sgem2014B42, pp. 191-198.

43.*** Romanian Standard Association, SR EN 12390-3:2005, Testing hardened concrete, Part 3: Compressive strength of test specimens, 2011.

44.*** Romanian Standard Association, SR EN 12390-5:2005,Testing hardened concrete, Part 5: Flexural strength of test specimens, 2009. 45.*** Romanian Standard Association, SR EN 12390-6:2010,Testing hardened concrete, Part 6: Split tensile strength of test specimen, 2010.

Manuscript received: 6.04 .2018 